\begin{tabular}{|c|c|c|c|c|c|c|}
\hline \multirow{4}{*}{ Impact Factor: } & ISRA (India) & $=4.971$ & SIS (USA) & $=0.912$ & ICV (Poland) & $=6.630$ \\
\hline & ISI (Dubai, UAE & $=0.829$ & РИНЦ (Russia) & $=0.126$ & PIF (India) & $=1.940$ \\
\hline & GIF (Australia) & $=0.564$ & ESJI (KZ) & $=8.716$ & IBI (India) & $=4.260$ \\
\hline & JIF & $=1.500$ & SJIF (Morocco) & $=5.667$ & OAJI (USA) & $=0.350$ \\
\hline
\end{tabular}

\section{SOI: $1.1 /$ TAS $\quad$ DOI: $10.15863 /$ TAS \\ International Scientific Journal Theoretical \& Applied Science}

\author{
p-ISSN: 2308-4944 (print) e-ISSN: 2409-0085 (online) \\ Year: $2020 \quad$ Issue: 03 Volume: 83
}

Published: $30.03 .2020 \quad$ http://T-Science.org
QR - Issue

QR - Article
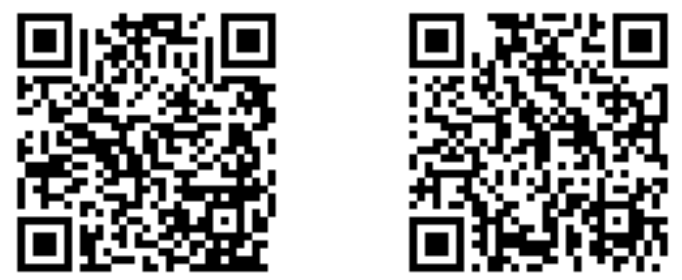

Maftuna Sadullaevna Asadova

Tashkent Institute of Architecture and Civil Engineering

Assistant

Department of Economics and Real Estate Management

Khurshidjon Shukhrat ugli Kakhramonov

Tashkent Institute of Architecture and Civil Engineering

Assistant

Department of Economics and Real Estate Management

\title{
BLOCKCHAIN TECHNOLOGIES IN THE DIGITAL ECONOMY OF UZBEKISTAN
}

\begin{abstract}
Today, the potential of digital economy and blockchain technologies is extremely promising. By the Decree of the President of the country as of September 2, 2018, the activity of companies in the field of crypto-active and blockchain technologies was launched. In addition, these technologies are being introduced to the public sector on the basis of public-private partnerships. Implementation of the most promising and strategically important projects for the development of the digital economy, as well as the development and implementation of blockchain technologies is one of the topical issues of today.

Key words: blockchain technology, economics, efficiency, digital economy, currency, cryptocurrency, bitcoin, money, blockchain, mining.

Language: English

Citation: Asadova, M. S., \& Kakhramonov, K. S. (2020). Blockchain technologies in the digital economy of Uzbekistan. ISJ Theoretical \& Applied Science, 03 (83), 155-159.

Soi: http://s-o-i.org/1.1/TAS-03-83-33 Doi: crossef https://dx.doi.org/10.15863/TAS.2020.03.83.33

Scopus ASCC: 2000.
\end{abstract}

\section{Introduction}

\section{UDC 330}

Today, the digital economy and a number of related technologies are rapidly entering our lives. Therefore, in order to further accelerate the development of the state and society, the President of the Republic of Uzbekistan in his address to the Oliy Majlis on December 28, 2018 [1] on the most important priorities for the development of digital economy said: "We need to develop a national digital economy concept". On this basis, we need to implement the program "Digital Uzbekistan-2030".

In this regard, it is important to note that the Decree of the President of the Republic of Uzbekistan dated February 19, 2018 № P-5349 "On Measures for Further Development of Information Technology and Communications" focuses on ensuring information security.
In pursuance of this Decree, the Cabinet of Ministers of the Republic of Uzbekistan "On additional measures to introduce and further develop the digital economy in the Republic of Uzbekistan" on August 31, 2018 defines the goals and objectives of the digital economy in order to create conditions for accelerated development of modern information technologies in the public administration system.

In the Decree of the President of the Republic of Uzbekistan "On Measures for the Development of the Digital Economy in the Republic of Uzbekistan” № PP-3832 dated 03.07.2018 were identified the following as the most important tasks for the further development of the digital economy:

- Training of qualified personnel with practical skills in the production and use of blockchain technologies.

- Ensuring close cooperation between government bodies and businesses in the 


\begin{tabular}{|c|c|c|c|c|c|c|}
\hline \multirow{4}{*}{ Impact Factor: } & ISRA (India) & $=4.971$ & SIS (USA) & $=0.912$ & ICV (Poland) & $=6.630$ \\
\hline & ISI (Dubai, UAE & $=0.829$ & РИНЦ (Russia & $=0.126$ & PIF (India) & $=1.940$ \\
\hline & GIF (Australia) & $=0.564$ & ESJI (KZ) & $=8.716$ & IBI (India) & $=4.260$ \\
\hline & JIF & $=1.500$ & SJIF (Morocce & $=5.667$ & OAJI (USA) & $=0.350$ \\
\hline
\end{tabular}

implementation of innovative ideas, technologies and developments for the further development of the digital economy

- All-round development of cooperation with international and foreign organizations in the field of cryptocurrency and blockchain technologies and attraction of highly qualified foreign experts in the field of production.

- Creating a legal framework for the implementation of blockchain technology, taking into account international experience.

Successful implementation of these decrees and decisions requires knowledge of the basic concepts of the digital economy. The digital economy is a system of human economic research that involves the widespread introduction of electronic and information and communication technologies in the production, distribution and consumption of community goods [2]. In our country, the digital economy is at an early stage of development. The term "digital economy" was introduced to scientific practice by Manuel Castels, a Spanish and American sociologist and a leading researcher of the information society [3]. He published his three-volume monograph "Information Age: Economics, Society and Culture". Today, the digital economy is not yet fully formed and is widely studied by many economists.

\section{Main part}

Today, the scientific study of laws, trends and opportunities for the development of digital economy in Uzbekistan, in particular, the degree of penetration of information technologies in various sectors of the economy, is extremely important. The success of large-scale reforms in our country is directly linked to the introduction of innovations in the national economy. In this regard, it is important to improve the digital economy, and to research its economic, political, social and legal basis [4].

It is worth noting that today users are actively using Telegram messenger to order food. Various internet shops and electronic payment systems are also actively developing. That means our citizens rely on electronic transactions. Only today, users are making small transactions that don't cost much, and are not quite ready to raise average purchases. The challenge now is to promote medium and large economic transactions and financial transactions through digital technology [5].

Digital economy has terms like its own currency (cryptocurrency, bitcoin), money saving card (blockchain), computation methods (mining).

Bitcoin cryptocurrency is a payment system currency based on a cryptographic coding system, rather than a trust, which allows payments directly between participants without any intermediaries (bank or other financial instruments). At the same time, without controlling bodies, each participant can also issue the coins with the use of a system based on complex mathematical algorithms [6].

Blockchain is a technology that allows participants to transfer assets securely to one another without intermediaries. For example, blockchain can keep records of money transfers. In cryptocurrencies, the blockchain is used to record information about who, who, and how many virtual transactions [7].

We can say that the development of the digital economy is considered in three main segments:

- sector of suppliers and buyers of real goods and services

- software and technology developers sector

- infrastructure in the form of legislative base, personnel training system, all types of data transfer and storage channels

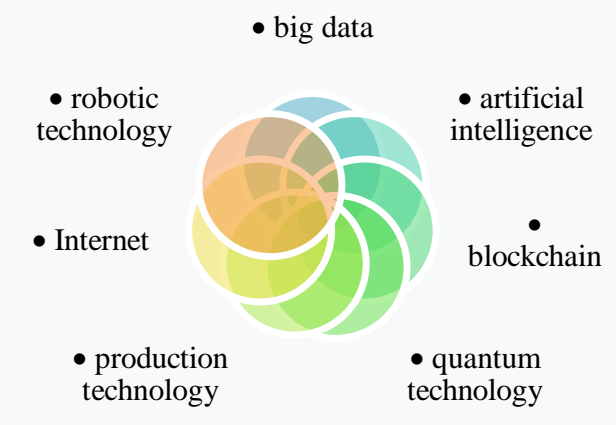

Pic. 1 Segments of the digital economy

In this regard, a number of countries, such as Switzerland, England, Israel expressed a desire to create their own virtual currencies using blockchain emission technology [8].
On the one hand, the introduction of blockchain and other digital technologies will certainly increase the reliability of public virtual currencies, and on the other hand, such an approach is incompatible with the idea of cryptocurrencies and cannot be fully opposed 


\begin{tabular}{|c|c|c|c|c|c|c|}
\hline \multirow{4}{*}{ Impact Factor: } & ISRA (India) & $=4.971$ & SIS (USA) & $=0.912$ & ICV (Poland) & $=6.630$ \\
\hline & ISI (Dubai, UAE & $=0.829$ & РИНЦ (Russia & $=0.126$ & PIF (India) & $=1.940$ \\
\hline & GIF (Australia) & $=0.564$ & ESJI (KZ) & $=8.716$ & IBI (India) & $=4.260$ \\
\hline & JIF & $=1.500$ & SJIF (Morocce & $=5.667$ & OAJI (USA) & $=0.350$ \\
\hline
\end{tabular}

to them. In any case, all countries should prepare their financial and economic systems for parallel circulation of several currencies, some of which are unregulated [9].

Currently, there are numerous methods and complex software products that allow large data processing, such as IBM, Oracle, Microsoft, HewlettPackard, eMC, Apache Software Foundation and others. The sources of information needed to handle big data can be:

- Logs of behavior of internet users;

- GPS signals to motor vehicle companies;

- Information on all transactions of the bank;

- Information on all purchases in the large retail network;

- Information from numerous city ip-video cameras;
- Information from large manufacturers, equipped with the technologies of industrial internet, etc.

The main difference between blockchain technology is that data is stored in a distributed network that is created and maintained by all participants multiple times, and this leads to [10]:

- makes it impossible to break or modify it;

- each recorded information has its own history, which allows to check the origin and authenticity of the information;

The features of creating a database make it more resilient to hacker attacks or illegal actions.

The listed features of Blockchain technology provide cryptocurrency reliability, namely:

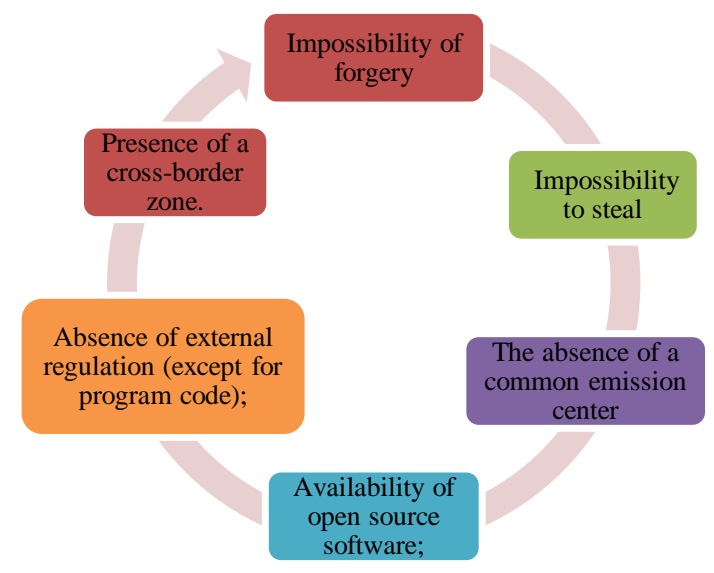

Pic. 2 Advantages of the digital economy

Apart from reliability, cryptocurrencies also attract users with ease of use and minimal transaction costs. The value of Bitcoin (or any other cryptocurrency) is determined by the demand and supply on the special exchanges (the cryptocurrency or the virtual currency exchange). In other words, many virtual currencies are a form of social contract, not material security.

\section{Conclusion/Recommendations}

The choice of the state to develop the digital economy opens up new dimensions in the field of information technology and, in general, in the field of electronic document management. The turning towards digital technologies has been driven by the development of the worldwide Internet and highquality communication.

As a result, there is an opportunity to exchange and collect large amounts of data, which in turn enables us to process, predict, make informed decisions and benefit in a variety of ways.
For all of this, it is necessary to create an appropriate infrastructure, in other words, a global information platform ecosystem. However, there is a need for data loss, business loss, job cuts, security risks, and modernization. These issues need to be addressed as soon as possible, because delays in these risks carry serious risks.

Nowadays we are witnessing how technology is radically transforming the service industry. In addition, new business models such as Uber are emerging, which can lead to direct customer and supplier relationships. This shows that information technology is slowly replacing people.

This is the digital economy. It is not clear how dramatic changes will be in our country due to the digital economy. Under current technical backwardness, digital transformation of the industry raises doubts about the rapid evolution.

In a global business, such as the transition to a digital economy, much depends on the government's position. It is important that not everyone is tied to a single state platform that unites and converts 


\begin{tabular}{|c|c|c|c|c|c|c|}
\hline \multirow{4}{*}{ Impact Factor: } & ISRA (India) & $=4.971$ & SIS (USA) & $=0.912$ & ICV (Poland) & $=6.630$ \\
\hline & ISI (Dubai, UAE & $=0.829$ & РИНЦ (Russia & $=0.126$ & PIF (India) & $=1.940$ \\
\hline & GIF (Australia) & $=0.564$ & ESJI (KZ) & $=8.716$ & IBI (India) & $=4.260$ \\
\hline & JIF & $=1.500$ & SJIF (Morocce & $=5.667$ & OAJI (USA) & $=0.350$ \\
\hline
\end{tabular}

everything, that is, "The task of the state is not to do anything in the role of business, but simply to prevent business."

The task of the state is to create common rules, and the business will change and develop based on these general rules, as laws will change the business environment and increase competition. Not because of a serious new common platform, but because of the emergence of an infrastructure that is closely linked to the many independent organizations and products that each has their own business.

However, it is important to develop the required standards and protocols at the highest quality level. In our view, this is a business that is interested in science, which can determine the economic needs of its outcomes, which is a step towards making the state more friendly to its goals. In other words, the digital economy can combine government, business and science. In order to be able to integrate with other international systems and practical mechanisms in the digital economy, data models and documentation in the "common window" mechanism must be established according to international standards and recommendations.

When compiling a list of data, which includes the initial list of messages and documents that need to be adapted, as well as the formation of a national data model, they should be described and defined in accordance with international standards.

The development of e-commerce in Uzbekistan as part of the digital economy can be conditionally divided into two phases: 2015. Until 2015, the country was actively working on the development and preparation of the regulatory framework.

In 2015, the Republic of Uzbekistan adopted the concept of e-commerce development for 2015-2018, which is aimed at further improving the main directions of e-commerce development in the medium term, expanding the competitive environment, creating modern infrastructure and creating new jobs, shapes and ways.

However, to date, the measures outlined in the concept have not been fully implemented. For example, a number of decisions on development of ecommerce in the legal framework have not been adopted. In particular, on May 14, 2018, President of the Republic of Uzbekistan Shavkat Mirziyoyev signed a Resolution "On measures to accelerate the development of electronic commerce". This document outlines a number of measures to improve ecommerce in Uzbekistan.

The average user of e-transactions in Uzbekistan ranges from 50,000 to $200,000 \mathrm{UZS}$. Along with global indicators, an Uzbek consumer uses a mobile phone to make an electronic transaction because it is more convenient and has a number of convenient applications.

With regard to product selection, many respondents preferred to buy clothes and household appliances and electronics over the Internet. Cars and real estate became the expensive goods on the internet. This can be explained by the fact that the user is not yet ready to spend large sums of money online

Concerning the problems of online purchase of goods, it is worth noting that almost all respondents had difficulties with payment, poor quality of goods and services, time of delivery and cost. Thus, based on the data obtained from the public opinion poll, we can note a number of problems and disadvantages that impede the development of e-commerce in Uzbekistan, including:

1. Population's distrust of electronic transactions;

2. High cost of delivery;

3. Low quality of goods and services;

4. Low computer literacy.

However, the population of Uzbekistan is ready to implement e-deals, but it faces a number of issues that affect the user and consumer relationships and slow the development of e-commerce in Uzbekistan. The age of information technology has set new ideas and rules for economic development.

The digital economy is a market model with great potential in our country because:

- Information is a priority, though the resource is not limited at all;

- Network market is huge and democratic, and the main thing is that network boundaries are easily washed away;

- The success of the project or company is no longer dependent on the number of employees and the size of the financial assets;

- Hardware capacities become multiple, universal, wearable and non-wearable means;

- The conditions of competitive struggle will change, as in the digital environment, agile intellectual solutions will outperform any strong physical base.

One of the key features of the digital information market is its speed and ease of decision making. A significant production base is at last place here. Large corporations that seem to be eternally and have a significant share in the network markets have, in a few years, replaced companies with no history at all. Thus, one cannot wait for the passage of the "number" fashion. This is a natural and brutal phase of evolution, with those who live by the rules and scope of the last century.

Thus, there are no clear criteria for assessing information assets. But it is the way that opens up a huge profit margin to proactive and entrepreneurial companies and individuals. Whoever comes first gets what he wants, and those who come after are only able to take the rest. It would not be far-fetched to think that old business schemes are one hundred percent anachronistic.

The boundaries between networks are disappearing, new opportunities are emerging, but at the heart of any commercial relationship there is 


\begin{tabular}{|c|c|c|c|c|c|c|}
\hline \multirow{4}{*}{ Impact Factor: } & ISRA (India) & $=4.971$ & SIS (USA) & $=0.912$ & ICV (Poland) & $=6.630$ \\
\hline & ISI (Dubai, UAE & $=0.829$ & РИНЦ (Russia) & $=0.126$ & PIF (India) & $=1.940$ \\
\hline & GIF (Australia) & $=0.564$ & ESJI (KZ) & $=8.716$ & IBI (India) & $=4.260$ \\
\hline & JIF & $=1.500$ & SJIF (Morocco) & $=5.667$ & OAJI (USA) & $=0.350$ \\
\hline
\end{tabular}

always one simple desire - to sell or buy goods or services. Consistently adapting existing assets to changed game rules is the only right and, most importantly, effective solution in this situation.

In our country, the following processes should be implemented in the digital economy:

- business models and a portfolio of existing services:

- standards of behavior in relations with clients and partners;

- corporate culture with a particular emphasis on the training and motivation of personal content;

- Responsibility and regulation of IT departments using virtualization, cloud technologies;
- organization of company infrastructure taking into account new technologies, software and hardware requirements of environment, interests of clients and partners.

The foregoing shows that the business model of a company can be incorporated into the elements by which changes to improve any one, leaving the passive assets in the process. Thus, the digital economy is more susceptible to volatile physical assets. The new technologies do not break existing funds and mechanisms, and a good understanding of what's happening in a timely audit is just enough incentive to start moving in the right direction.

\section{References:}

1. (2018). Decree of the President of the Republic of Uzbekistan dated February 19, 2018 "On measures for further improvement of information technologies and communications". Retrieved from https://lex.uz/docs/3564970

2. Kabulov, V.K. (1998). Algorithmization in social-economic systems. (p.320). Tashkent: Science.

3. Bekmurodov, T.F. (2004). Research on computer technology and informatics in Uzbekistan: history and prospects. Collection of scientific works of the NGO "Cybernetics". (pp.78-84). Tashkent.

4. Revenko, N. S. (2017). Digital economy of the USA in the era of information globalization: current trends. Journal "USA and Canada: economy, politics, culture", № 8(572), pp.78100.

5. Bondarenko, V. M. (2017). Worldview approach to the formation, development and implementation of the "digital economy". Journal "Modern it and it education", http://inecon.org/docs/2017/Bondarenko_IT_20 17
6. (n.d.). Digitalization: history, prospects, digital economies of Russia and the world. Retrieved from

http://www.uppro.ru/library/strategy/tendencii/c yfrovizaciya-trend.html

7. Odintsov, S.A., \& Vashchenko, A.V. (2016). The development of theories of the information society and the concept of "Cyber-space", Political Mathematical Electronic Scientific Journal of the Kuban State Agrarian University, №121, pp. 1-14.

8. Kulikova, E.I. (2018). Digitalization as the main trend in the development of financial services. Journal "Financial life”, №4, pp. 67-70.

9. Pichikov, O.B., \& Ulanov, A.A. (2017). Risks and imperfections in the development of the digital economy on the modern stage. Journal "Insurance business", №11, pp. 3-8.

10. Alekseyenko, O.A., \& Ilyin, I.V. (2018). Digitalization of the global world and the role of the state in the digital economy. Journal "Information society", №2, pp. 25-28. 